\title{
Reminiscences By Liberty Hyde Bailey, First President of The American Society For Horticultural Science, 1905-1907
}

\author{
John G. Seeley ${ }^{1}$, Department of Horticulture, Cornell University
}

\begin{abstract}
Bailey was born March 15, 1858. His service to Cornell University was considerable and the University hoped to celebrate his $90^{\text {th }}$ birthday anniversary in special style. That couldn't happen on his birthday, however, because Bailey was in tropical America hunting for new species of palms; so the party was held April 29, 1948. Various dignitaries lauded Bailey's work and influence on everything he touched. Then he responded. I am sure you will find it interesting.
\end{abstract}

$$
\text { and now, a "word" from Liberty Hyde Bailey.... }
$$

To all my friends - felicitations! To all others - my sympathy!

This is not my anniversary. Some six weeks ago I flew out of South America on my $10^{\text {th }}$ exploring trip to that continent. I came down through the clouds on a shore of a virginal and spice-fragrant island to celebrate my anniversary. I drove 23 miles across that island to the capital-over through the interior and between the mountain ranges. I recognized many of the forest trees, the plants and the animals, and thought that in a general way I could recognize the geological history of the ranges. And as I drove, I saw three great palm trees standing in and above the forest, one of them marking the regional range many miles long. I know they were new species - never described and never named by man. On that journey I celebrated my anniversary all alone. Not one soul on that island knew - God was my witness - and I loved it! It brought back to me the days of my youth in the woods. I gathered together on this journey, as on others, my specimens, which are some times bulky and heavy. On different islands and in different countries I made arrangements to have these specimens dried and pressed and sent to me-from eight different countries. The first one came in today.

Now the sentiments that have been expressed here tonight are not my sentiments. This is not my celebration - it is yours. I might have a very different point of view and estimate of the activities that you have heard recited, but I cannot escape the fact that I have lived more that half the lifetime of this republic.

I saw the frontier broken out and I was a part of that frontier. I have seen the great West develop. I remember when the gold spike was driven that connected the railroad from the East to the West-north of Great Salt Lake. I remember the assassination of Abraham Lincoln. We did not think so much of Abraham Lincoln in those days - we pioneers out in the West-because he was a rail-splitter. This was given to him as a sort of political title. We were all rail-splitters.

The rail fence in the early days, particularly in all the wooded countries, was a zig-zag fence. It easily divided the lines of properties and kept cattle within certain areas. I was a rail-splitter. There is no memory of my youth that is more precious to me to this day than the splitting of fence rails.

Our farm was cut out of the primeval forest. As far as I understand it, not one tree had been cut out. It had been taken up in the year 1843. There was a record of three hundred Indians wigwamed on that land and a part of it on the north end was open country. About ten acres were burned over every year by the Indians and there they trapped the passenger pigeons which flew in such enormous numbers when they

${ }^{1}$ I have a large box of materials, by or about Liberty Hyde Bailey, and recently discovered there a mimeographed copy of his reminiscences given extemporaneously at a dinner in honor of his $90^{\text {th }}$ birthday anniversary. The copy was provided by the Department of Public Information at Cornell University.

Appreciation is expressed to Dr. Francis Stark, ASHS Archivist/Historian, for his assistance in preparation of this paper for publication. were beginning to fly in the spring that the sky was darkened. I was with the Indians on many mornings trapping passenger pigeons in great nets which they had secured and some of which I think they themselves had woven on frames stuck on edge. Captive pigeons were allowed to go up on a string and when the squabs were flying over they would see the passenger pigeon, begin to swirl and circle, come down on the ground to feed, and then the nets were sprung over them. I ran with the papooses and I knew something of their language.

The chief once turned to my father and said, "Now you are a white man and you have bought this land. I suppose we can never trap pigeons here."

He said, "You may trap pigeons on this place as long as you live."

And they did until finally they were run out by the incursions of the superior whites. They were in our house-in and out. They were

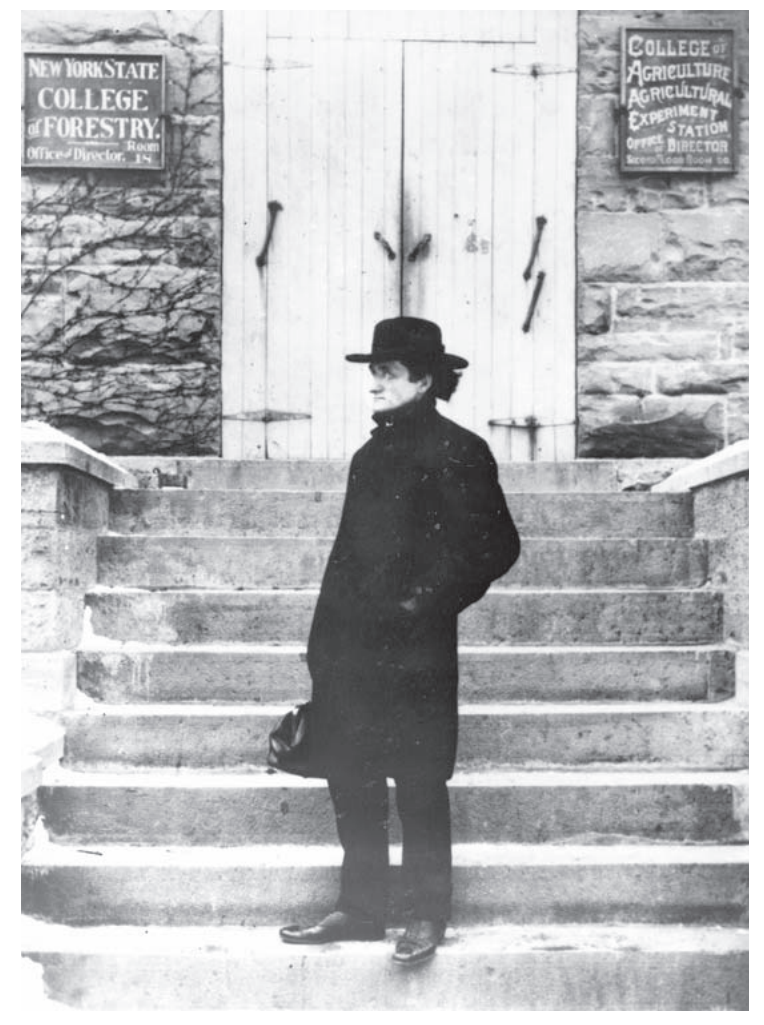

Liberty Hyde Bailey on steps of Morrill Hall at Cornell University.

Photo credit: Div. of Rare \& Manuscript Collections, Carl A. Kroch Library, Cornell University, Ithaca, NY 14853-5302 
not great people but they were good people and they were honest. The chief would come to our house now and then. He spoke little English and my father knew a little Indian. There would be some sort of conversation.

The three of us, my father, my older brother and myself always carried our guns with us when we went into the fields to work and they were stuck up in the corners of the rail fence in the hope that we might see something that would add to the kitchen fare. One day an Indian came by as my father had brought down a coon from a remaining tree. The whites did not eat coons, the Indians did. The Indian asked my father if he could have the coon - my father said yes. The Indian said, "I will bring you a saddle of venison (I remember very well when I first tasted beef). The Indian didn't bring the saddle of venison.

When the chief came along and my father told him about the incident, the chief said, "The Indian's name."

"No, I don't know his name."

"How does the Indian look?" And then the chief said, "Ah, Mr. Bailey-Mr. Bailey, bad Injun lie just like a white man."

But he got the venison.

And those rails! You cut your white ash logs in the spring from 11 to 13 feet long. Get those logs as near as possible without knots, and without crude seams and without burls. And you pile them up in $\log$ piles till in the autumn they are ready to split into rails. You roll them out on a level piece of ground. You look it all over and the bark is on it. Perhaps you see a crack somewhere - at one end, or in the middle, or at the other end where you can thrust in your axe or your wedge. Those wedges are iron wedges made at the blacksmith's shop. Whenever you split a rail you need six wedges. You may not use them all. Perhaps only two or three would be sufficient. You have a great maul made of a burl from a beech tree with a good big stiff handle on the end. If the crack is big enough you drive in your wedge-you drive it with your burl-you drive it with your maul. If not, you open it slightly with the edge of your axe and then you open another split further down the log, being sure that you follow the line of the seam's crack so that finally when your log splits apart it will not have splints on it all the way.

And so you drive the wedges in and finally the log falls open and reveals all the fragrant mysteries in the interior of it and all the fragrance of accumulated years. Then you lay it down on its face and you split again until you get all the rails that you can get from that one log. Then it's stacked up carefully, horizontal but straight, and your father comes along and looks it all over and pronounces it good.

Then, as other times are free, you lay your rail fence along your borders. Takes time to be sure but in those fence corners strange plants begin to grow, woodchucks begin to burrow, robins build their nests on the edges where the rails overlap, and finally you have a scene from life.

On the border there is the opening up of this great country. In the wooded areas, where rail fences were evidences of division there were evidences of prosperity; there were evidences also of good, hard, honest work. Now and then in some back country you could see one zig or two of a rail fence left. I think there is not one in this part of New York State. Rail fences are gone. When I came here the rail fences were more or less in existence. I owned a piece of land that I bought down there by the lake and made a farm there. Now it has gone back again - most of it - into the forest from which I took it.

There are some stump fences, but the zigs are nearly all gone. If any of you know of a zig or two of an old zig-zag fence within my reach let me know - I will sit on that zig - I will revive my youth. To me under those circumstances all the world was good.

My father was a Vermont Puritan. We belonged to the Congregational Church. His father was a farmer up in Vermont, a deacon of the church and a member of the legislature. I knew one winter when he couldn't get back and forth to the home down in Windham county when a son was born.

Now there was a great abolitionist, one of the earliest in that part of the country, and they wrote to him to say that a son was born in the house - what shall he be called? And the letter came back and said, "Call him Liberty - all shall be free." The son died in his early years. Another son was born and as was the old New England custom, the second son took the first son's name. That second son was my father.
Well, that good old Puritan-I remember that a man came along one day and complained about the weather. My father was a silent man, but when he spoke he spoke to the point. He said,

"Did you make the weather?"

"Why no, of course not."

"Who made the weather?"

"God made the weather."

"Then keep your mouth shut; to complain about the weather is blasphemy."

And all my life I never heard my father complain about the weather. If rain came when we worked, we ran into the barn, or the house, or got under a tree and took up other pieces of work. There was never any complaint. I have never any objection to the weather whatever it may be for the good and sensible reason that I can't change it. And why, therefore, should I make myself any trouble?

Animals were then in their place and they were all good. Whatever the human beings might have been in that community, I thought that all the animals, at least, lived sensible lives. They lived a life that in some way was natural to them. We used to say that the Lord had ordained them.

I was brought up to feel that I must walk a straight path through life and if I met the devil I was to hit him between the eyes. Now as those well read in demonology know, that is an old, old notion come down with the race, whereby man must assert himself and assure his independence.

I found that the roads through our parts of the world were not straight - they were here and there-everywhere. I expected to see the devil every night. I was not allowed to read any novel except one and that one was "Pilgrim's Progress" and the devil was there with the flames coming out of his bowels. I expected to meet him any night but it soon dawned on me that there must be more than one devil. Different devils had dominion over each phase of existence. There must be other kinds of ogres and djinns - and there must be devilettes.

I have heard my father tell a woman she would make a good secretary for Satan, and the wife of one of our woodsmen was possessed of seven devils. One day as I was going by, I saw him bring her out in his arms and heave her into the rain barrel. I think the rain barrel boiled over. You see, the road through life was not quite as straight in the beginning as I thought it might be.

I had a mother. Her father tramped as far west, walking through the wilderness from Detroit, as Kalamazoo. Other tribes were coming up from the South to settle in the great new territory of Ohio and Indiana and the wonderful Wolverine peninsula and amongst those immigrants coming up was one of the Harrison family - Catholics from the James River country in Virginia. She was my mother. I remember at four years of age of standing by the bed and seeing her pass into the silence.

My stepmother was all I could desire but she was not my mother. I used to hear many statements about her, sometimes of a soft and poetic tendency which has always interested me and I regret, of course, that I missed that influence.

But one of that tribe became a part of my childhood. On the beautiful prairie land just near Schoolcraft, Kalamazoo County, Michigan, you will find a great monument to Basil Harrison. He never had any legal education but he was the Solomon of the frontier. He settled so many difficulties that he was called Judge Harrison. James Fenimore Cooper lived with him when he came west. It is certain that some of the Leatherstocking stories may have come from there and like all others on the frontier he was a bee hunter. And old Vogel, the bee hunter in one of Cooper's novels, was Basil Harrison.

He had a remarkable reputation for good health and for longevity. Once when I spoke of him in some unfortunate speech I made somewhere, I had a letter from a woman and she said, "My dear Liberty, my mother was a Harrison, she was a sister of your mother-we are cousins. The Harrisons have always prided themselves on telling the truth. You have slipped. But there is some way whereby you may redeem yourself. It is reported that in making this speech you said that Uncle Basil was 105 when he died-he was only 103." 
We had a few books. My father was a great reader. He had graduated from an academy in Vermont which is still active (I saw it last summer) and the house in which he was born still stands. But I was to read no books which were not proper for a young man. I couldn't read a novel but there were three books I could always read; I could read the Bible and I have read it through-every word - as I also have read El Koran. And I have read all of Confucius far away in China. I read Edwin Armour's Light of Asia and all I can find of Zoroaster. I have read in a Taoist temple far back in China and I have seen Taoism practiced. It was a religion of China before Buddhism was introduced.

The old temple in which Ilived was occupied by a good many monks, most of whom had never seen that curious animal - the white man. There were thousands of those people. They said they did not know how old the temple was but they knew it had been used actively for at least a thousand years. Thirty or forty idols in that temple-I think of those some were as modern as Marco Polo because I recognized one as Marco Polo's mustachio. I paid obeisance to him and made all the genuflections to him I could, but learned of course that the idols do not operate, and do not come to life, until you drop a coin in the back and you can hear it tinkle.

I covered every one of those idols with my drying papers - the first time probably the cobwebs had been taken off in a thousand years. They did not object to that and a good many novelties I found in that region also.

I went to college 71 years ago. I was fascinated by books. One of the speakers has told about the Darwin I was allowed to read and other books which seen to be serious and useful I was also allowed to read. And settlers brought books - often with no covers - sometimes with half the book gone-sometimes no title page. But one which interested me immensely was a book about natural history. I took it to the teacher in the school and said I would like to have a class in natural history. She called for volunteers - nobody volunteered. She said, "I will take you as a class, one student as a member of a class-you will recite to me every day for a year one page from this book. I did and every day she asked me one question which I was to answer her next day. She did not know the answer. She said she did not know it, but she knew how to teach. And I was on my mettle all the time to answer her unequivocally the next day - for one whole year. I recited as the only pupil in the class.

I gave the book back to the owners. To this day I do not know who wrote it, I do not know its title, but it was one of the best schoolbooks that I have ever come across.

And in this book by Darwin (I had never seen a dictionary - I had never attended a graded school-I am not sorry for it) ... when I read Darwin I found words I could not understand, and I could not find anyone who could understand them or know them. When someone came along I asked them what this funny word was but I couldn't find anyone who knew. The word was "a priori". I took it to the teacher and she said, "Well, that was a language called Latin." (I was curious about that - the Indians knew no Latin.) So I took that problem down to the teacher. She said, "I know Latin." I don't know where she was educated but I found out that she read Latin fluently and loved the old language. I said to her, "Can we have a class in Latin?" (You can see the schools were organized differently in those days than they are now.) Though she taught reading, writing and arithmetic, she had the right to teach anything else that she wished. She said, "I would love, Liberty, to teach you Latin."

She called volunteers (and got one volunteer) and Willie Pollock and myself recited every day for one year until we got through a Latin grammar. Of course you cannot learn Latin that way, but nevertheless some flavor of the language and some interest in it has remained with me from that day until this.

And books - oh well, there has been much exaggeration about the number of books that I have written. One of the reasons is that I was an editor of books for a good number of years. The President of the American MacMillan Company was George W. Brett and after some books of mine had been published he said to me, "Mr. Bailey, whenever you have a new book well enough along to know its title, send me the title so that I can send you a contract." I said, "What about the subject?" and he said, "I don't care anything about the subject-I don't want to see the manuscript. I will publish every book you write." His successor is his son of the same name-he sits right there.

I could write books. I suppose that several hundred have gone through my hands as editor, but we looked it up some four or five years ago and we found that I, myself, had written and published only 65 books. We are reading proof now on a large one. I have all the illustrations done for still another and it is about half written, but my opus magnum has not yet been begun.

But I have written more books than I have published. In another conversation many years ago a young horticulturist came to me and said, "I want you to know that I have written a book--it is all done on a certain subject. I hope you haven't written one on the same subject." I said, "Yes, I have - it's all complete." He said, "That is our difficulty, we cannot publish books - you get us first. It's very discouraging." I said, "Very good, I will burn my book." I went home and I burned that book - every leaf of the manuscript and every picture. I once thought that I would write an essay on "Books I Have Burned," but now I have forgotten how many there are. I know there were at least six that were complete and ready for the printer-one of them was on an historical subject to which I devoted most of my time for nearly a year.

Early in the century great responsibility came on me-I foresaw it. I knew that I could not get much help and that I was going to be in trouble. I needed to have companions and on the farm down the lake, there on the edge of a limestone cliff, I built me a cabin with my own hands, that projected over the edge of the gorge - so I could see a family of raccoons as they were playing on the ledge at the base. There I wrote a novel. I sat all the summer writing that novel, enjoying every minute of it. And there were helpful people in that novel-male and female. It was the best book I ever wrote. Now bear me testimony-I didn't say it had any value. Along in the autumn as with my old friend James Whitcomb Riley "when the frost is on the pumpkin and the corn is in the shock," I went down to that cabin, unlocked the door and took the manuscript home. We had a good large fireplace and I sat before the fire during those autumn nights and read one chapter each night and as I read the pages I dropped them into the fire. It burned vividly. Nobody has ever known one word of that book. I have forgotten the title-I have forgotten the characters in the novel save one. It was a great solace to me for many years till now when the mists have dimmed.

I have not thought of the writing of books as necessarily being for publication, but I have always enjoyed the physical exercise of writing a book. I have never yet dictated anything for print. I never shall. All my books went to the printer in hand writing. Printers then could read handwriting - now they cannot. And in the period of which I have spoken I became the editor of a very ambitious magazine. That was in 1901 , in the days when the storms began to gather. It was a very large magazine - I think the first one of the large size now, of our large and florid magazines - COUNTRY LIFE IN AMERICA.

If any of you have access to the first one of the volumes you will be interested to see the editorial policy in that magazine. The text had its own place and the advertising had its place-but in those days advertisement had not yet become a great organization of its own. For years I was editor at the same time when my many, many books were being published. I was a member of a club in New York City. Nobody heard of it outside my family but I attended monthly meetings. The club was composed of authors, editors and publishers. I knew those people-many of them.

St. Gaudens was mentioned; I knew him. I knew Mark Twain. I knew the poets of that day, and they wrote poetry for that magazine. One of the poems was an original from Rudyard Kipling, living then in Vermont. I think that poem has never been assembled into any of the anthologies. Then I got one from Joaquin Miller-perhaps you don't know who Joaquin Miller was. He was the poet of the Sierras. He had been to Europe and with his curious frontier dress and so on, he had created quite a sensation. We had supposed that his poetry was largely superficial - of no consequence-as the Cornell Countryman, in a recent issue, said mine was not, but his Columbus and some other things were remarkable compositions. I knew Joaquin. He lived on the hills across the bay from San Francisco. He had erected monuments of stone to Moses - to Abraham - and to Job and to other people who were of that era. Once he and I, long years ago, were guests at the Bohemian Club in San Francisco. He came down with his pants in his boots, with a long duster, hair down to his shoulders - wearing a 
big straw hat. It was a custom in the Bohemian Club, as on other days when I had been there, for guests to tell a story about themselves and as I happened to be the youngest of the guests it was my privilege to tell the last story.

I could think of nothing but a relatively recent occurrence in Western New York. I had been on some extension work. I was going out of Rochester. The train I was on was full of people carrying bundles - they had been up shopping. Amongst them was a woman with two little children and two or three baskets of provender and as she started to get off (with the train on a curve) the steps were high up from the ground. There was no one to help her off. I saw her predicament and jumped off the back of the car. I ran down and helped her off. She was somewhat overcome, but when the train started out and she knew she should say something, she said, "Oh, homely people are so good!"

Joaquin sat back in his chair, twiddled his thumbs and laughed - and she meant every word of it too. Well, here is the manuscript torn apart, here is the manuscript of this poem which I accepted and changed somewhat. I will read two or three stanzas. It is written in longhand on brown paper, which is faded now. Perhaps I cannot make it all out!

The hero of the coming strife

Is he who deals not death, but life.

I count this man the coming man...

The crowning glory of God's plan.

$* * * *$

This last stanza follows:

Each man a hero-a lion each!

Behold what length of limb

What length of life, of love-

What daring reach to deep-hived honeycomb-

What strength, those clean outdoor Adams, Virile, clean as nature in her vernal green.

He hears, he hears - as a prophet hears

The morning music of the spheres.

I knew the poets of that day-I have treasured their memory.

I think some sophistries have come into life. I am impressed with the way in which the unusual appears to men and women now, as if they must be lifted out of life rather than participating in life and all its thrills-its exhilarations, with all the ecstasies which will be diversions in it. I wonder how much they strengthen life for the real enjoyment of it.

Oh, ye who gaze on ecstasy -

The dancer all in white;

Cover your gleaming eyes

For she is death's own acolyte.
She dances on the moonstone floors

Against the jeweled peacock doors.

With roses flaming in her golden hair

Her sad eyes are wistful there.

Oh, ye who gaze on ecstasy-

The dancer all in white-beware!

Lest she, ah softly, strangely, rapturously-

Those doors all bronzed and gleaming blue,

Lure thee into the bourne of night.

The measure of life is in the daily living of it and the acceptation of it for all it is worth or, at least, for all you can make of it - and you can make much of it! We are now devoting ourselves to science. I am afraid some of us feel that science is to be the solvent of all of our difficulties but do not be deceived, it will not be so. Science will give us better understanding - better bases for philosophy, an ideal groundwork for satisfactions, for enjoyment, but it is doubtful whether the mind of man can ever understand the universe. For every puzzle that we uncover two more appear that are hidden. It is our privilege, we ought to think it is our obligation, to try to understand these discoveries - to utilize such as we need, perhaps, of the inventions, just for the purpose that we may partake in their evolution, and be better prepared for whatever may come.

Now we come back to Kipling:

When earth's last picture is painted,

And the tubes are twisted and dried;

When the oldest colors have faded,

And the youngest critic has died.

$* * * *$

Then no man shall work for money,

And no man shall work for fame.

But each for the joy of the working...

And each in his separate star,

Shall paint the thing as he sees it-

For the God of things as they are.

I have arrived at the end of life. I am planning a great journey. It may not transpire. That doesn't matter-the point is interesting. My life has been a continuous fulfillment of dreams. It appears to me that everything I saw and did has a new and perhaps a more significant meaning every time I see it. The earth is good! It is a privilege to live thereon!

In my travels I do not see palm trees alone. My first interest is always the people and their institutions. I pay my taxes in Ithaca, but I am a citizen of the world. I am at home wherever I stop. I have never been homesick. I thank all my lucky stars that 60 of those golden years have been lived at Cornell. 